Article

\title{
Long-Term Displacement Monitoring of Slow Earthflows by Inclinometers and GPS, and Wide Area Surveillance by COSMO-SkyMed Data
}

\author{
Roberto Vassallo ${ }^{1}$, Stefano Calcaterra ${ }^{2}$ (), Nicola D'Agostino ${ }^{3}{ }^{(0)}$, Jacopo De Rosa ${ }^{1, *}$, \\ Caterina Di Maio ${ }^{1}$ and Piera Gambino ${ }^{2}$ \\ 1 Scuola di Ingegneria, Università della Basilicata, Viale dell'Ateneo Lucano, 10, 85100 Potenza, Italy; \\ roberto.vassallo@unibas.it (R.V.); caterina.dimaio@unibas.it (C.D.M.) \\ 2 Istituto Superiore per la Protezione e la Ricerca Ambientale (ISPRA), Servizio Geologico d'Italia, Via Brancati, \\ 48, 00144 Roma, Italy; stefano.calcaterra@isprambiente.it (S.C.); piera.gambino@isprambiente.it (P.G.) \\ 3 Istituto Nazionale di Geofisica e Vulcanologia (INGV), Centro Nazionale Terremoti, Via di Vigna Murata, \\ 605, 00143 Roma, Italy; nicola.dagostino@ingv.it \\ * Correspondence: jacopo.derosa@unibas.it; Tel.: +39-340-5974380
}

Received: 29 February 2020; Accepted: 6 May 2020; Published: 8 May 2020 updates

\begin{abstract}
With reference to two slow earthflows in structurally complex clayey formations of the Italian southern Apennines, this paper shows the results of a long-term displacement monitoring using integrated systems of inclinometers and GPS, and their comparison with PSInSAR data. A fixed-in-place and traversal inclinometer system, first installed in 2004, recorded both the shear displacements along the slip bands, and the internal deformations of the landslide masses. A GPS network of permanent stations and benchmarks, installed in 2006-2007 in 23 strategic points of the slope, allowed for the temporal continuity of displacement monitoring. The two long series of data allowed to evaluate the factor scaling of the PSInSAR COSMO-SkyMed data, although the component of the displacement vector along the line of sight (LOS) was small. PSInSAR data allowed for the monitoring extension to houses and rigid structures that acted as reflectors. The joint data analysis allowed for the comprehension of the main features of the landslides' kinematics.
\end{abstract}

Keywords: landslide; monitoring; displacement; inclinometer; GPS; DInSAR

\section{Introduction}

Earthflows in structurally complex clayey formations [1] are widely diffused in the Italian Apennines. Earthflows are the second most common type of landslides in wide hill and mountain areas of the northern Apennines, where they prevalently occur in argillaceous lithologies [2]. The widespread diffusion of earthflows in clayey and flysch sequences has been reported for some areas of the southern Apennines by Revellino et al. [3] and Pellegrino et al. [4] who, in an area of $70 \mathrm{~km}^{2}$, recognized 484 landslides, $95 \%$ of which were of the earthflow type.

Earthflows are frequently characterized by alternate phases of surges and very slow movements or quiescence [5-8]. In very slow conditions, an almost steady-state motion occurs, with limited seasonal variations, generally due to changes in pore water pressures [9-13]. Many very large earthflows remain in a dormant state for many decades, allowing roads and buildings to be built on them [6]. The aim of studies such as that presented in this paper is to identify the main landslide mechanisms, which can give an indication of triggering factors and possible effective mitigation measures. To this aim, the monitoring of displacements plays a fundamental role. However, due to the very slow movements, a long monitoring period can be necessary. Comprehensive and long monitoring can be achieved by combining different methods: airborne LIDAR and aerial photographs [14,15], radar interferometric 
technologies (DiNSAR), and Global Positioning System (GPS) [16-18], inclinometers and DiNSAR with GPS data [19] or topographic measurements [20], DiNSAR and statistical elaboration [21].

With the aim of enriching the technical database on very slow earthflows, and analyzing their kinematics, this paper presents some experimental results on the displacements of two clayey landslides occurring in the Costa della Gaveta slope, close to the city of Potenza, Italy: the homonymous Costa della Gaveta earthflow, and an earthflow occurring in the western sector of the Varco d'Izzo landslide system (Figures 1 and 2). The movements of both the landslides are very slow; however, they cause severe damage over time to houses and infrastructure. Some houses must be evacuated, and the highway and railway must be continuously monitored and frequently maintained. To reduce the landslides' risk, since 2005 the slope is monitored by systems of piezometers and tensiometers, inclinometers, GPS stations, total stress cells [22-24], distributed fiber-optic strain sensors [25], and other systems specific for the chemical characterization of the subsoil [23,24].

In this paper, the displacement data of the long-term monitoring carried out by a large number of traversing and fixed-in-place inclinometer probes are reported together with those obtained by continuous GNSS (Global Navigation Satellite System) stations and discrete GPS surveys. The data integration provides a 15-year uninterrupted robust displacement series. Furthermore, interferometric PSInSAR satellite data are examined. The spatial and temporal extension of the dataset allowed the construction of the field of displacement rate and the evaluation of its evolution.

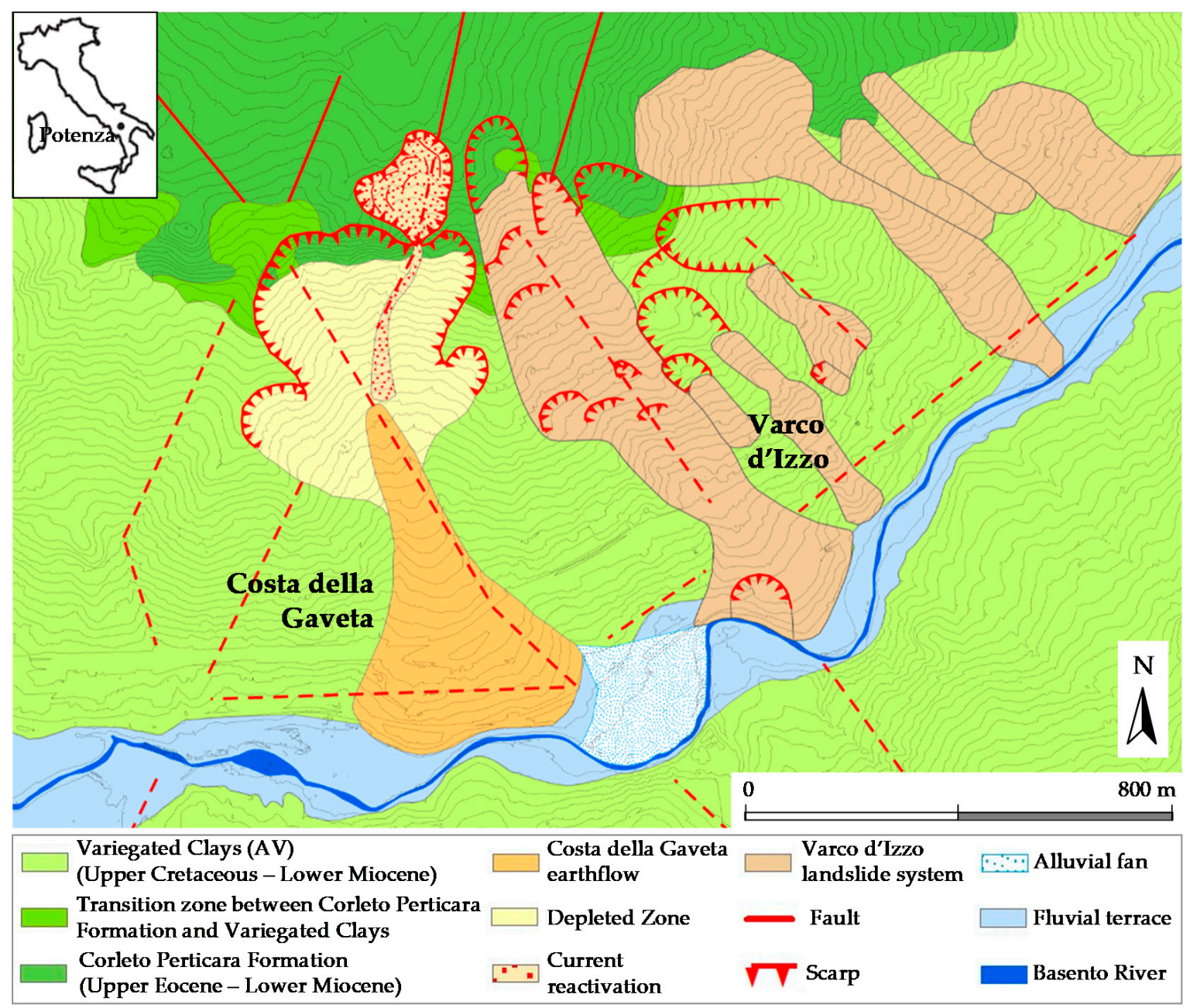

Figure 1. Geological map of the Costa della Gaveta earthflow (redrawn from [24]), and the Varco d'Izzo landslide system (redrawn from [26]). 


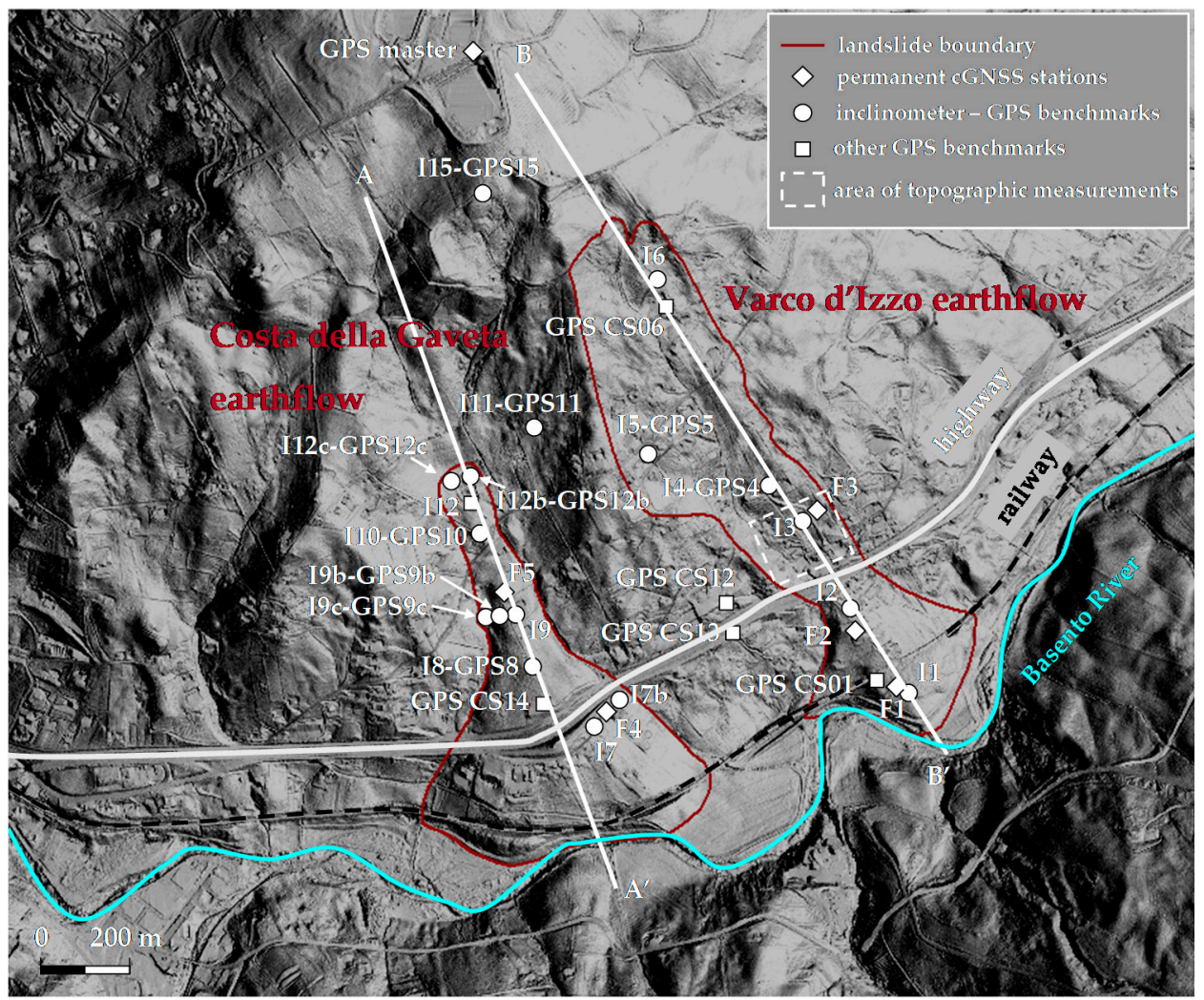

Figure 2. Costa della Gaveta and Varco d'Izzo earthflows and location of inclinometers, GPS stations and benchmarks, and area of topographic measurements.

\section{Geological and Geomorphological Outline}

The landslides under examination occur in the southern slope of the Costa della Gaveta hill, on the left flank of the Basento river valley, east of Potenza city (Figure 1).

The geological structure of the hill is mainly linked to Miocene orogenic transport that deformed the Mesozoic Lagonegro successions, creating wide folds with the axis approximately oriented NS, EW. The folds are truncated by faults EW and thrusts along the eastern and western flanks of the main mountains $[27,28]$. The tectonic phases of Pliocene and Pleistocene resulted in further folds truncated by a high angle fault system with Apennine and anti-Apennine orientation [29]. The complex fault system also involved the Costa della Gaveta hill, and the outcropping sequence of Variegated Clay and Corleto Perticara formations $[30,31]$. The two formations present a high degree of fractures and joints and are cut by a system of faults with NW-SE orientation intersecting a system with NE-SW orientation.

The Variegated Clay Formation (Upper Cretaceous-Lower Miocene), first described by Ogniben [30], is comprised of a succession of chaotic, heterogeneous, severely tectonized scaly clays and marly clays, passing upwards to calcareous marls, calcilutites, and calcarenites. These terrains outcrop from the top to the bottom of the slope, where they are covered by the Quaternary deposits of the Basento river alluvial terraces. The Corleto Perticara Formation (Eocene-Oligocene), first described by Selli [31], which is partially heteropic to the terrains of the Variegated Clays, consists of alternating layers and benches of marly limestone, and massive calcilutites with both plane-parallel and wavy laminations. Between the two geological formations, a transition zone outcrops (Figure 1), constituted by different lithological horizons, where limestone and calcareous marl layers progressively prevail on marl and clay layers [32].

The Costa della Gaveta and Varco d'Izzo earthflows are a mixture of the materials of the two formations: a clayey matrix incorporates rock fragments, blocks, and disarranged strata of marly limestone and calcarenite. The fine matrix controls the landslides' behavior; its clay fraction c.f. ranges 
between $25 \%$ and $50 \%$, illite-muscovite, and kaolinite are the main mineral components. The liquid limit $\mathrm{w}_{\mathrm{L}}$ ranges between $50 \%$ and $100 \%$. The residual friction angle of the clayey matrix ranges between $6^{\circ}$ and $13^{\circ}$, depending on the clay fraction, clay mineral composition, and pore fluid composition [24]. The systems of faults have most likely influenced the first slope failures and the subsequent evolution of the landslides [24,32].

The main body of the Costa della Gaveta earthflow develops along the NW-SE fault (Figure 1). In the source zone, markedly depleted, localized erosion, rock falls, slides, and earth-debris flows periodically occur along the NE-SW fault, and feed the main landslide body [24,32]. This latter is characterized by an average inclination of about $10^{\circ}$, approximately $900 \mathrm{~m}$ length, 100 to $600 \mathrm{~m}$ width, and a maximum slip surface depth of about $40 \mathrm{~m}$ (Figure 3); the landslide volume is approximately $3 \times 10^{6} \mathrm{~m}^{3}$. According to Guida and Iaccarino [5], who analyzed a large number of landslides in the Basento river valley, and Urciuoli et al. [6], this landslide is one of the earthflows of the valley which has had three key stages. After a first stage A characterized by mobilization and flow, and a second stage B of flow within a well-defined lateral shear surface, the earthflow is currently in a slow-extremely slow sliding phase (stage C). A similar long-term evolution of active earthflows is described by Mackey and Roering [14] for a different geological context.

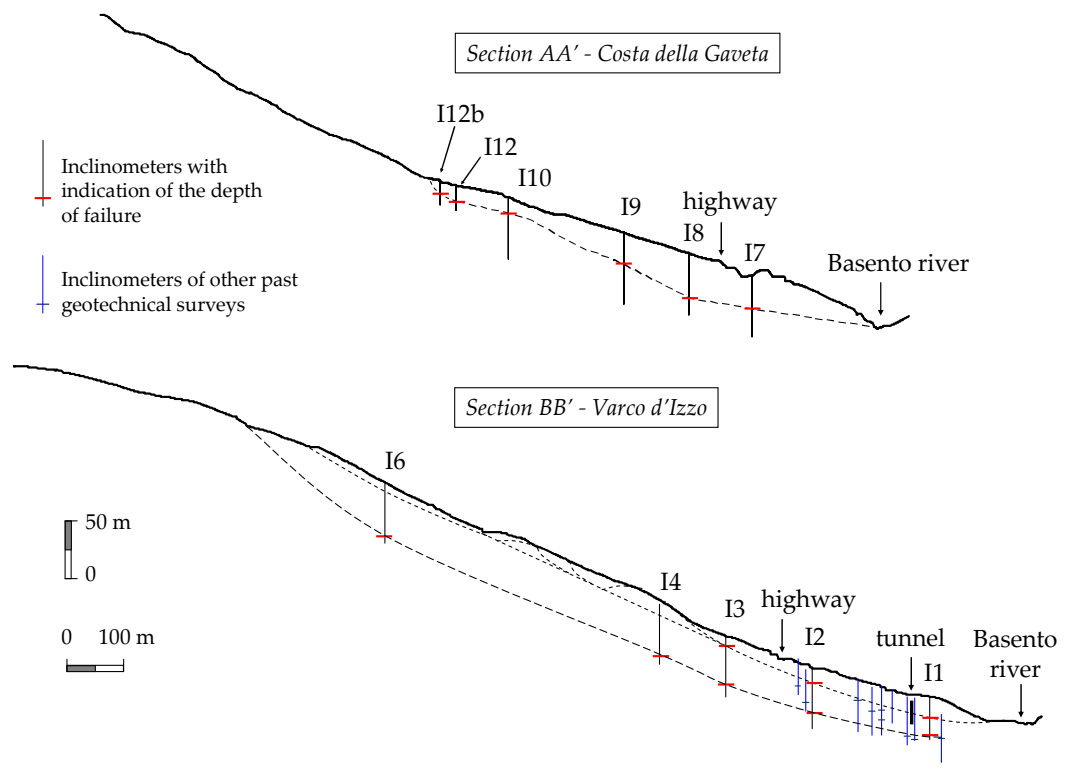

Figure 3. Sections $\mathrm{AA}^{\prime}$ and $\mathrm{BB}^{\prime}$ with inclinometers of recent and past surveys, depth of failures, and hypothesized slip surfaces.

East of the Costa della Gaveta earthflow, and in the same geological formations, the Varco d'Izzo landslide system develops. It is a huge and complex system (Figure 1) characterized by approximately $1.5 \mathrm{~km}$ maximum width. The system consists of several minor unstable bodies including slides (of earth, rock blocks, and even olistolites up to some $10 \mathrm{~m}$ ), and earthflows. The main earthflow, in the western and most urbanized zone [33,34], develops along a NW-SE fault almost parallel to that of Costa della Gaveta. It is characterized by an average inclination of about $10^{\circ}$, approximately $1250 \mathrm{~m}$ length, 150 to $300 \mathrm{~m}$ width, and multiple slip surfaces (Figure 3). In the accumulation, a local slide occurs in correspondence to a bend of the Basento river.

\section{Inclinometer Measurements}

\subsection{Methods}

Inclinometers were installed to determine the magnitude, rate, direction, depth, and time evolution of the landslides' deformations and movements [35]. The inclinometer system consists of 20 devices, 
installed from 2004 to 2018, which recorded data over different time intervals in each zone depending on the displacement rates. At the end of 2004, 11 boreholes were drilled to $50 \mathrm{~m}$ depth, i.e., well below the potential zone of movement suggested by borehole-core interpretation, and equipped with inclinometer casings. Further tubes were installed all over the monitoring period to replace those that had gone out of use for excess of displacements. Possible random or systematic errors were minimized by following recommended procedures for installation, measurement, and data processing [36,37]. Traversing servo-accelerometer probes with a precision of $1 \mathrm{~mm}$ per $20 \mathrm{~m}$ were used. Readings were generally taken in steps of $0.5 \mathrm{~m}$ (equal to the distance between the two spring-pressured wheels) and of $0.1 \mathrm{~m}$ in correspondence to concentrated deformations [22]. The spiral correction was verified to be unnecessary. In some boreholes (I9, I9b, I12, I12b), after the slip surface had been detected by discrete inclinometer surveys, fixed-in-place probes with automated data acquisition equipment were installed. The casings were mainly installed along the longitudinal axes of the earthflows' bodies (Figures 2 and 3). Some of them were installed along the transversal sections (Figure 4).

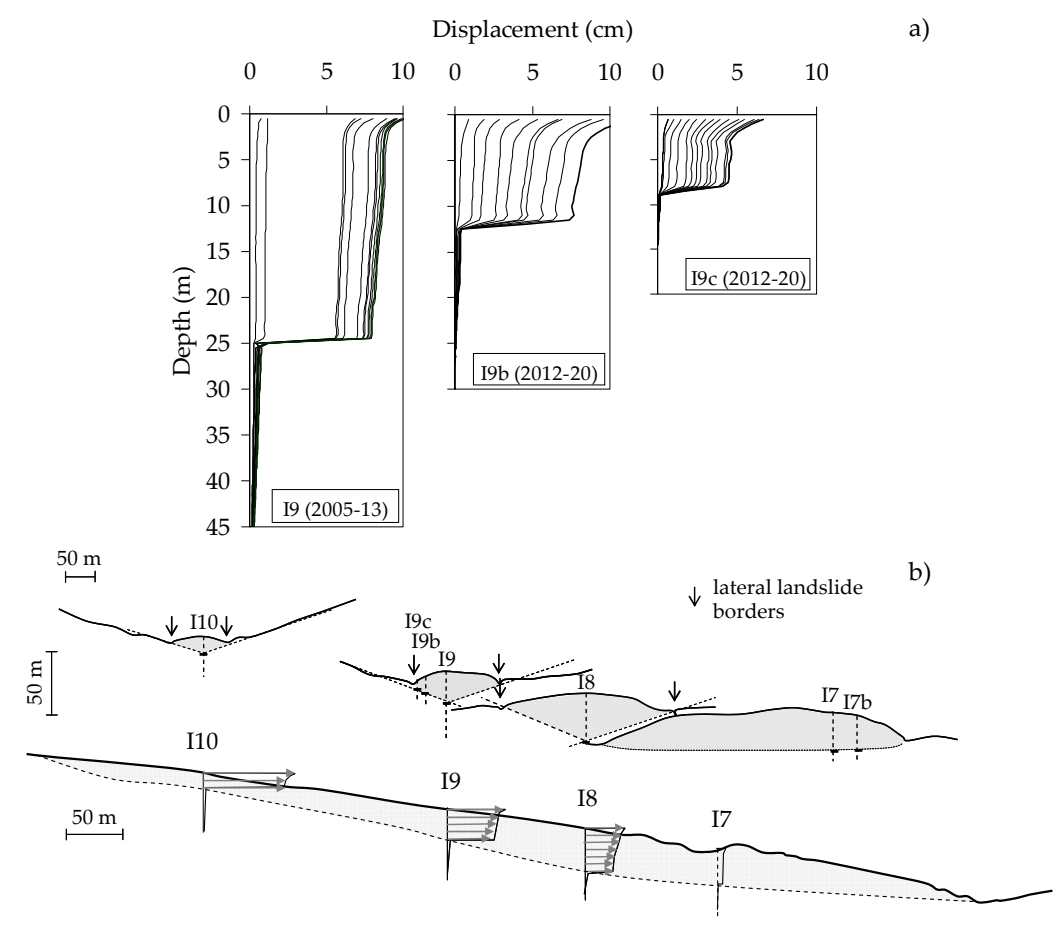

Figure 4. Costa della Gaveta earthflow: inclinometer profiles I9, I9b, and I9c (a); longitudinal section with inclinometer profiles relative to the same time period and transversal sections (b).

\subsection{Results}

Figure 3 reports the longitudinal sections of the two landslides hypothesized from inclinometers. Figure $4 \mathrm{a}$ shows the cumulative displacement profiles determined in some boreholes in the same transversal section of the Costa della Gaveta earthflow. The inclinometer profiles show that the tube deformations are concentrated in a thin band-which is considered to correspond to the slip band-and the internal deformations are negligible. A thickness of the band of about $0.5 \mathrm{~m}$ was inferred from inclinometer readings in $0.1 \mathrm{~m}$ steps. In I9c, close to the lateral landslide channel which collects superficial water, and probably because of the consequent higher water content of the $3 \mathrm{~m}$ thick cover, the highest internal deformations among the profiles of this landslide occur [22]. Notwithstanding this, concentrated sliding along a thin slip band is still the prevailing movement. Analogous profiles were provided by all the inclinometers of the landslide, consistently with data reported in the literature for the slow/extremely slow stage of this type of landslides [5-7] and of shallower earthflows [38-40]. 
Figure $4 \mathrm{~b}$, which shows some displacement profiles along the longitudinal axis and some transversal sections, shows that the displacement rates decrease in the downslope direction, whereas the depth of the slip surface and the area of the transversal sections increase. The transversal sections were reconstructed following Di Maio et al. [41], by generating the slip surface by two families of planes. The planes interpolate the ground surface of the flanks of the landslide channel and intersect the inclinometer verticals in correspondence to the depth of failure.

Figure $5 a, b$, which reports respectively the cumulative deep and superficial displacements against time, illustrates that the differences between the two sets of data are small, i.e., internal deformations are negligible. Both the figures show an almost linear time trend of displacements, with the average slopes of the time series, i.e., the average displacement rates, decreasing in the downslope direction.
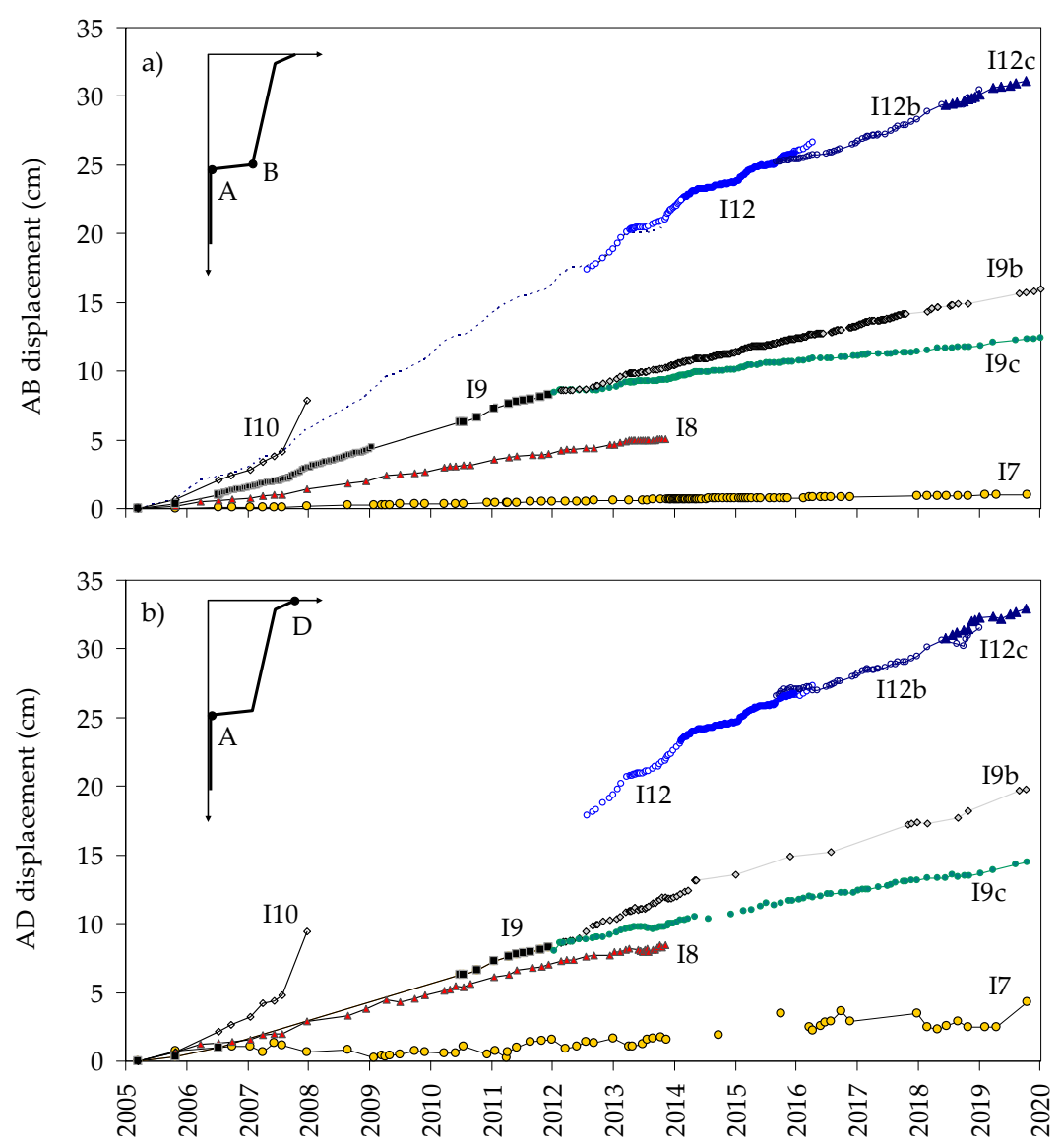

Figure 5. Time series of cumulative deep displacements $\mathrm{AB}(\mathbf{a})$ and superficial displacements $\mathrm{AD}(\mathbf{b})$ of Costa della Gaveta landslide, obtained from inclinometer data.

The inclinometer profiles of the Varco d'Izzo earthflow (Figure 6) indicate the presence of two main slip surfaces, important internal deformations, and displacement rates higher than those of the Costa della Gaveta earthflow. The longitudinal section BB' intercepts several inclinometers which indicate multiple slip surfaces (Figure 3). In correspondence to the railway tunnel, two slip surfaces were detected, at the depths of about $20 \mathrm{~m}$ and $40 \mathrm{~m}$, respectively. The earthflow develops along the shallowest slip surface [42]. In the accumulation, in correspondence to the entrance of the railway tunnel, and of a bend of the Basento river, a local landslide occurs. Figure 7, which reports the displacements against time recorded in several inclinometers installed since 1993, shows the variability of displacement rate from place to place and along a single vertical. The inclinometer I1, in the accumulation, provides a sufficiently long series with almost constant yearly displacement rates on both the slip surfaces. 


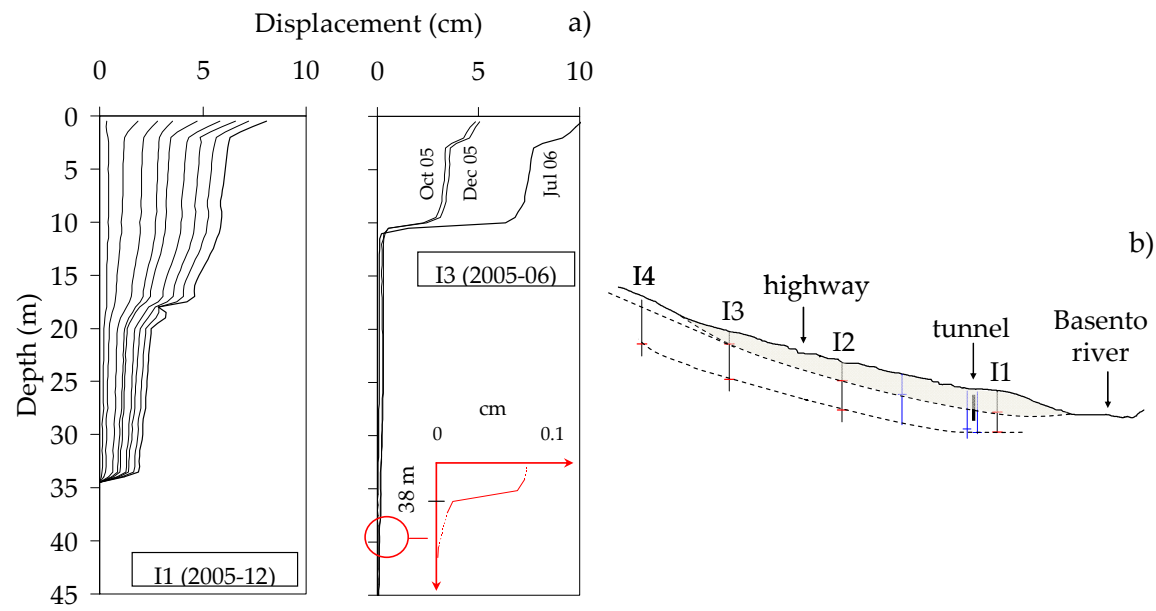

Figure 6. Inclinometer profiles I1 and I3 (a) and longitudinal section of the lower Varco d'Izzo earthflow (b). I3 went out of use in a year along the shallower slip surface, when the displacements on the deeper slip surface were small (as visible in the zoom relative to the profile of December 2005).

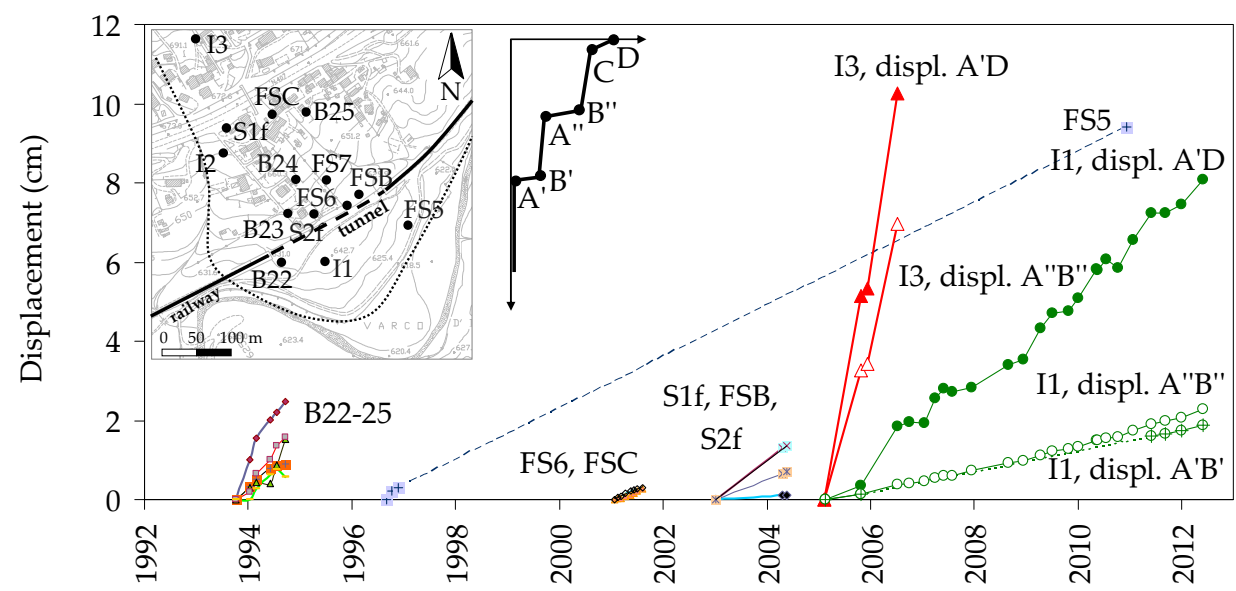

shear displacement along the slip bands (depth reported in brackets)

\begin{tabular}{|c|c|c|c|c|}
\hline - - B22 (34m) & 一- B23 $(19 \mathrm{~m})$ & $\triangle B$ B23 $(29 m)$ & $\because B 24(17 \mathrm{~m})$ & - B25 (12m) \\
\hline -- ¥-- FS5 (21m) & $\leadsto$ FS6 $(32 \mathrm{~m})$ & $\therefore$ FSC $(27 \mathrm{~m})$ & $-x-\operatorname{S1f}(22 \mathrm{~m})$ & - $-\mathrm{S} 2 \mathrm{f}(26 \mathrm{~m})$ \\
\hline —-FSB $(28 \mathrm{~m})$ & $\multimap \mathrm{I} 3(11 \mathrm{~m})$ & $\multimap \mathrm{I} 1(20 \mathrm{~m})$ & $\multimap-\mathrm{I} 1(34 \mathrm{~m})$ & \\
\hline
\end{tabular}

total displacement

$\rightarrow$ I1 $\rightarrow$ I3

Figure 7. Deep and total displacements in different areas of the Varco d'Izzo earthflow, obtained from inclinometer data (redrawn from Di Maio et al. [42]).

\section{GPS Data}

\subsection{Methods}

In 2006, GPS benchmarks were installed for the measurement of surface displacements by means of discrete surveys and, one year later, were integrated with continuous GNSS (cGNSS) stations (Figure 2).

The first network of 10 benchmarks surveyed using GPS technique was installed in 2006 in various zones of the slope and annual campaigns were carried out. Following the first inclinometer results, 6 cGNSS stations were installed in some sectors to better understand the kinematics of the landslides. They were installed in July 2007 and are still in use. In total, 17 benchmarks have been installed so far, with 14 still in use. 
The reference permanent station (master) was installed on the top of the hill, in an area considered stable, upslope from the landslides. It consists of a dual-frequency GNSS receiver and a choke ring antenna. Its position is periodically controlled relative to permanent stations of the EUREF network. Figure 8 shows its displacement trend and those of two other permanent stations of the same Region in the IGS14 coordinate system, which is consistent with the movement of the Southern Italian Apennines [43].
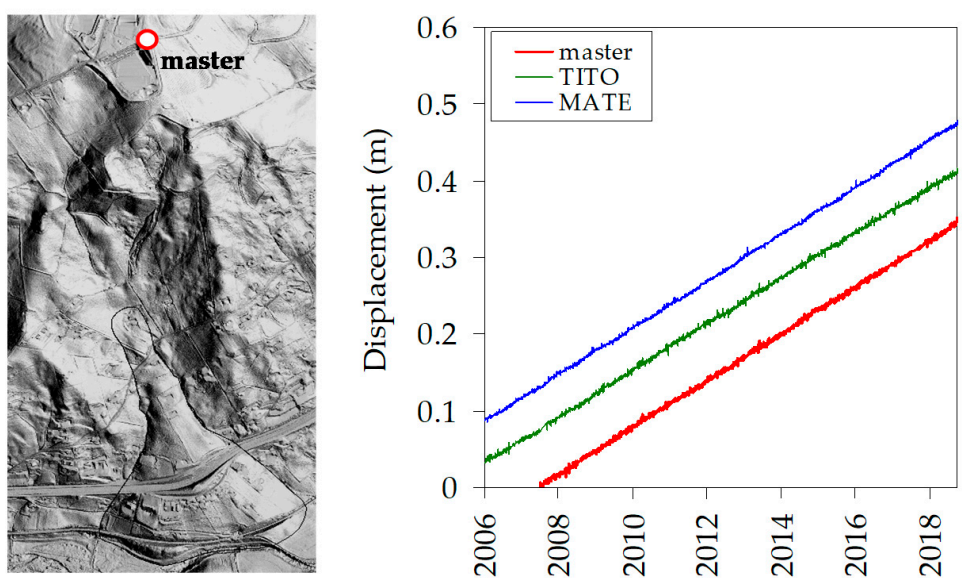

Figure 8. Displacement time series in the IGS14 coordinate system of the master station and two other permanent stations located in the same sector of the Southern Italian Apennines: MATE (operated by ASI-Italian Space Agency) and TITO (operated by CNR-National Research Council of Italy).

Three permanent stations were installed on concrete columns (F1, F3, F5), one on a concrete wall (F2), and one on a building (F4) with shallow foundations [44]. These permanent stations are equipped with a dual-frequency geodetic antenna. Continuous data, recorded at a $30 \mathrm{~s}$ sampling rate, are automatically transmitted to the head office of ISPRA. Here, the quality of raw data is controlled, RINEX files are created and the daily displacements, relative to the master station, are provided as an output by the Leica GPS Spider software. In this paper, the RINEX data available in $24 \mathrm{~h}$ batches were reprocessed to obtain three component daily positions. GPS data were reduced using the NASA Jet Propulsion Laboratory (JPL) GIPSY-OASIS II software. Precise point positioning mode was applied to the ionospheric-free carrier phase and pseudo-range data [45] using JPLs final fiducial-free GPS orbit products. Ambiguity resolution was applied using the wide lane and phase bias (WLPB) method, which phase-connects individual stations to IGS stations in common view [45]. Resolving ambiguities significantly reduces the scatter mostly in the east component time series. The ocean loading was computed from the FES2004 tidal model coefficients provided by the Ocean Tide Loading Provider [46] and applied as a station motion model. Satellite orbit and clock parameters were provided by JPL, which determined them using a subset of the available IGS core stations as tracking sites. The fiducial-free daily GPS solutions were aligned to IGS14 [47] by applying a daily seven-parameter Helmert transformation (three rotations, three translations, and a scale component) obtained from JPL [45].

The discrete GPS surveys, carried out in static mode, use the top of inclinometer tubes by an adapter constructed ad hoc [44], rigid walls (CS01 and CS14), and low concrete walls (CS13, CS06, and CS12). During the surveys, several geodetic receivers are employed using a 3D forced centering system in order to warrant the repetitiveness of measurements. The static positioning technique was used, with three site occupations and at least six hours' acquisition. The data processing was performed using Bernese software version 5.2 [48] and the coordinates of the stations were obtained by constraining some EUREF permanent stations with a processing strategy for regional GPS networks. The average precision (RMS) achieved was $2-4 \mathrm{~mm}$ and $5-10 \mathrm{~mm}$ for the horizontal and vertical components respectively. 
In order to increase the monitoring points in the most urbanized zone of the earthflow, close to inclinometer I3 and GPS F3, the displacements of 8 benchmarks installed on rigid structures were evaluated, by a polar method, elaborating the data obtained by an electronic theodolite (Kolida KTS 445 ) with $0.1^{\prime \prime}$ angular resolution and $2 \mathrm{~mm} \pm 2 \mathrm{ppm} / \mathrm{km}$ linear precision.

\subsection{Results}

The GNSS system provided data almost continuously since its installation. Figure 9a,b shows a good agreement, in the overlapping monitoring period, between GPS displacements and surface inclinometer displacements obtained in the same areas. The GPS data can thus be used to extend the displacement time series when inclinometers go out of use. In particular, it is worth noting that the GPS F3 allowed for the monitoring of the fastest zone of Varco d'Izzo earthflow after the inclinometer I3 went out of use. Its displacement rate is similar to that of inclinometer I3 and also to the rates detected by the topographic surveys (Figure 9b).
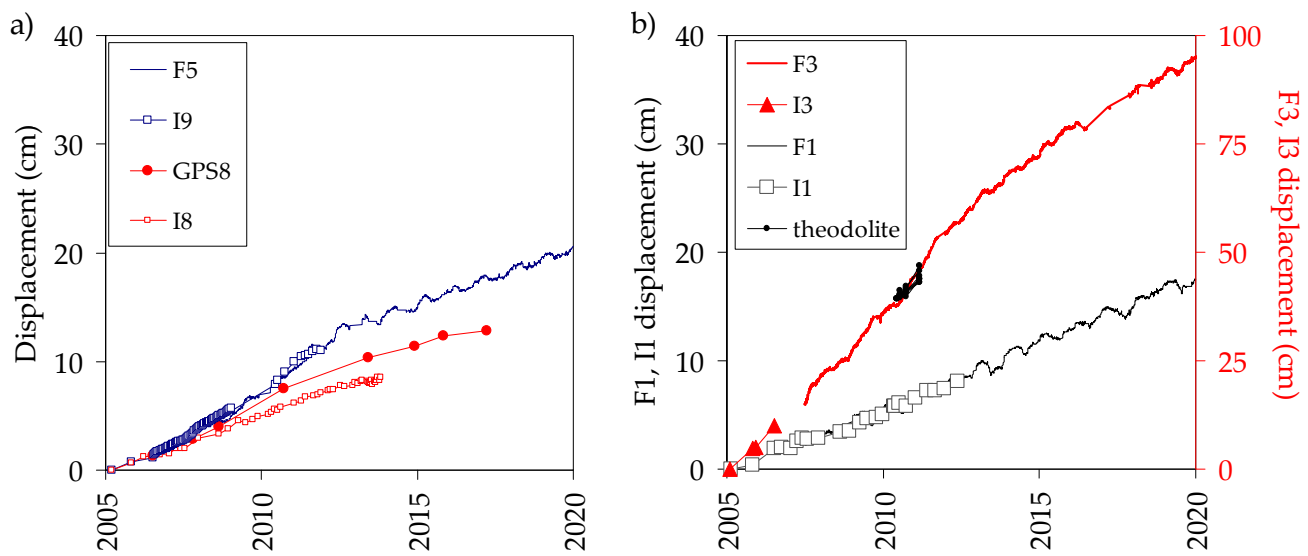

Figure 9. Comparison of: inclinometer and GPS data of Costa della Gaveta earthflow (a); inclinometer, GPS, and theodolite data of Varco d'Izzo earthflow (b).
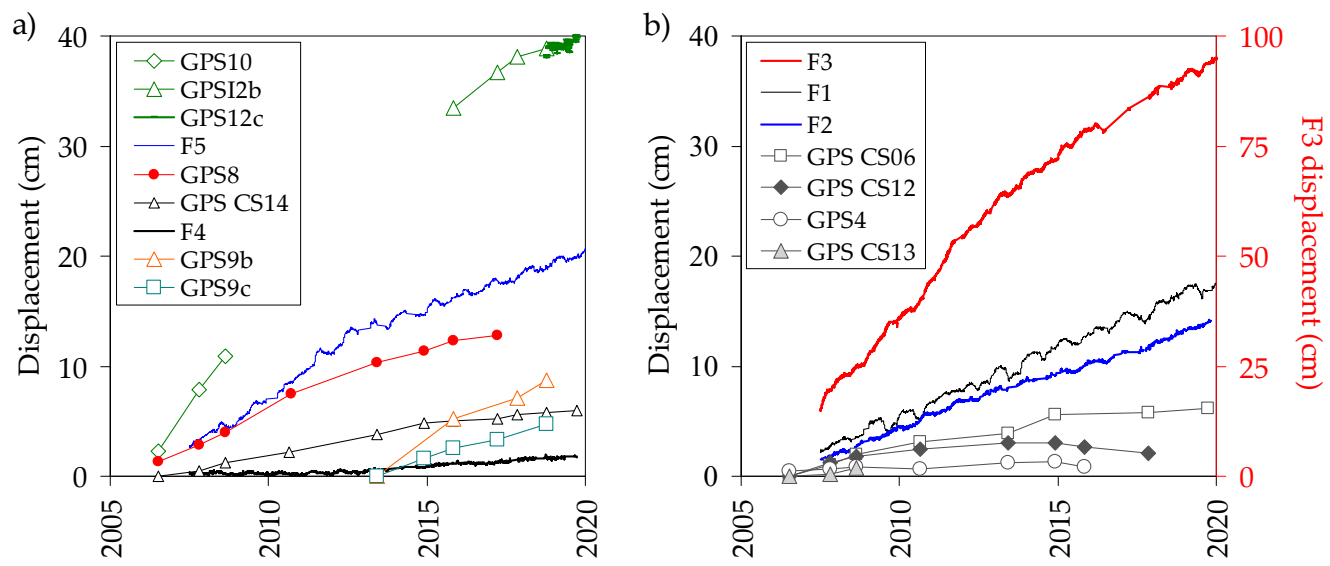

Figure 10. Displacements of GPS stations and benchmarks of Costa della Gaveta (a) and Varco d'Izzo (b) earthflows.

The available GPS data are shown in Figure 10 for the two landslides. The curves show that: the stations upslope from the highway are slightly decelerating (F3, F5, GPS8); those downslope from it are undergoing displacements with constant yearly rates (F1 and F2) or with slight acceleration (F4). Some stations (GPS CS06, GPS4) have not moved in the last 4 years. Seasonal data oscillations have affected the GPS stations installed on concrete columns with shallow foundations, reasonably due to seasonal swelling/shrinkage of the foundation soil [49]. 


\section{PSInSAR Data and Comparison with GPS and Inclinometer Data}

COSMO-SkyMed satellite PSInSAR data are available for the area from 2011 to 2014. They were processed within the PST-A: a high precision plan of remote sensing of the Italian Ministry of Environment [50]. Such data provide the displacement component along the satellite line of sight (LOS) which in this case is approximately WE and related to an SN ascending orbit. Since the landslides' displacements are approximately NS, just a small component of the total displacement is visible by the satellite and thus the displacement rates range between very low values and are rather dispersed (Figure 11). However, the availability of the long inclinometer and GPS data series makes it possible to evaluate the conversion factor from the LOS component to the horizontal displacement. The evaluation is based on the hypothesis that: (a) the azimuth of the scatterer displacement is the same as that of the closest inclinometer or GPS station, and (b) the inclination of displacements to the horizontal is $10^{\circ}$, i.e., equal to the slope inclination. Based on these assumptions, and considering the local characteristics of the satellite observation (i.e., azimuth and inclination to the horizontal of the LOS and the pass being ascending), the conversion factors were estimated by trigonometric calculations, following Di Maio et al. [20]. Their values are quite high (approximately from 3 to 5 depending on the considered zone), and even a $5^{\circ}$ azimuth difference implies a variation of up to $40 \%$.

The PSInSAR data, referred to as CSK data in the following, were analyzed in detail for the zones "a"-"j" of Figure 11. For the zones "a"-"d", they are compared to the GPS and inclinometer data in Figure 12. In the Costa della Gaveta landslide, a very good agreement of data can be observed (Figure 12a,b). In the Varco d'Izzo landslide, practically the same displacement rate is inferred in zone " $c$ " from the two types of data (Figure 12c). In zone " $d$ ", located between the highway and the railway tunnel, the displacement rates from CSK data are slightly higher than that of GPS F2 (Figure 12d) and rather uniform (Figure 13a).

The CSK data, having been validated by GPS and inclinometers, can be used to obtain information in the areas where other data is limited, such as zones "e-" $h$ ". Figure $13 \mathrm{~b}-\mathrm{e}$, which reports displacements against time, show linear time trends corresponding to horizontal displacement rates between $1 \mathrm{~cm} / \mathrm{y}$ and $6 \mathrm{~cm} / \mathrm{y}$.

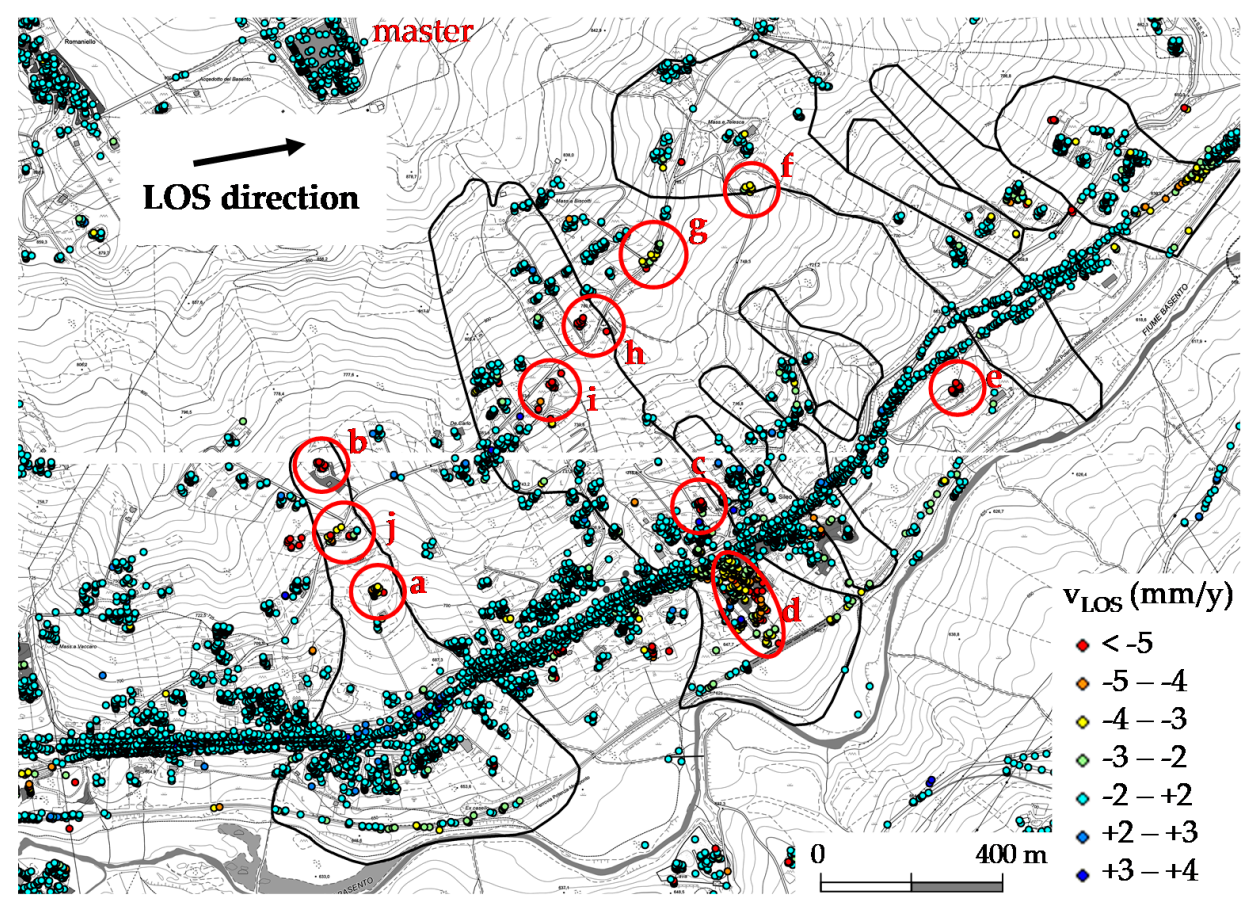

Figure 11. Average rates of the line of sight (LOS) displacement of monitored scatterers in the period May 2011-March 2014 evaluated from COSMO-SkyMed ascending data. 

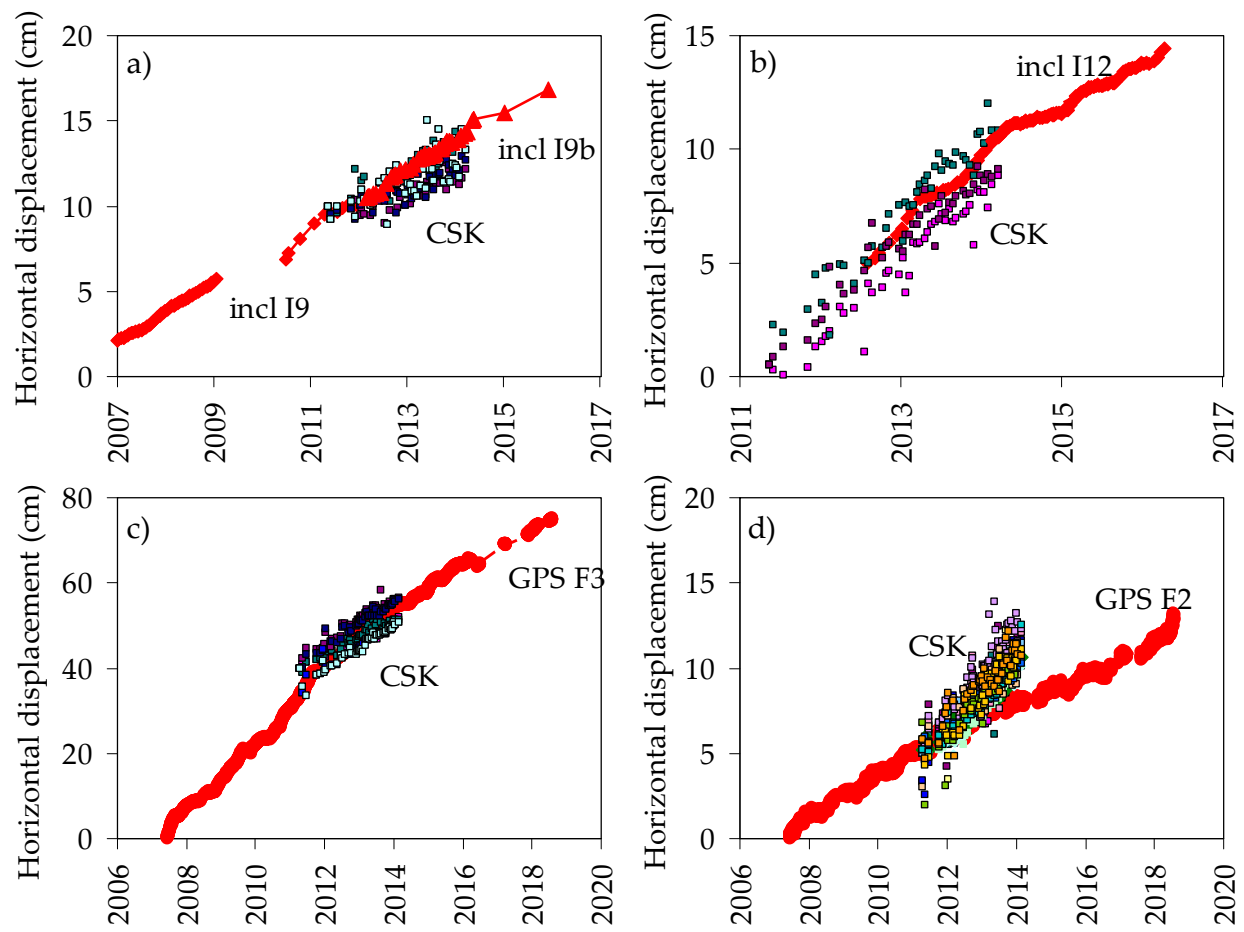

Figure 12. Comparison of displacements obtained from PSInSAR data, GPS, and inclinometers in zones (a), (b), (c), and (d) of Figure 11.
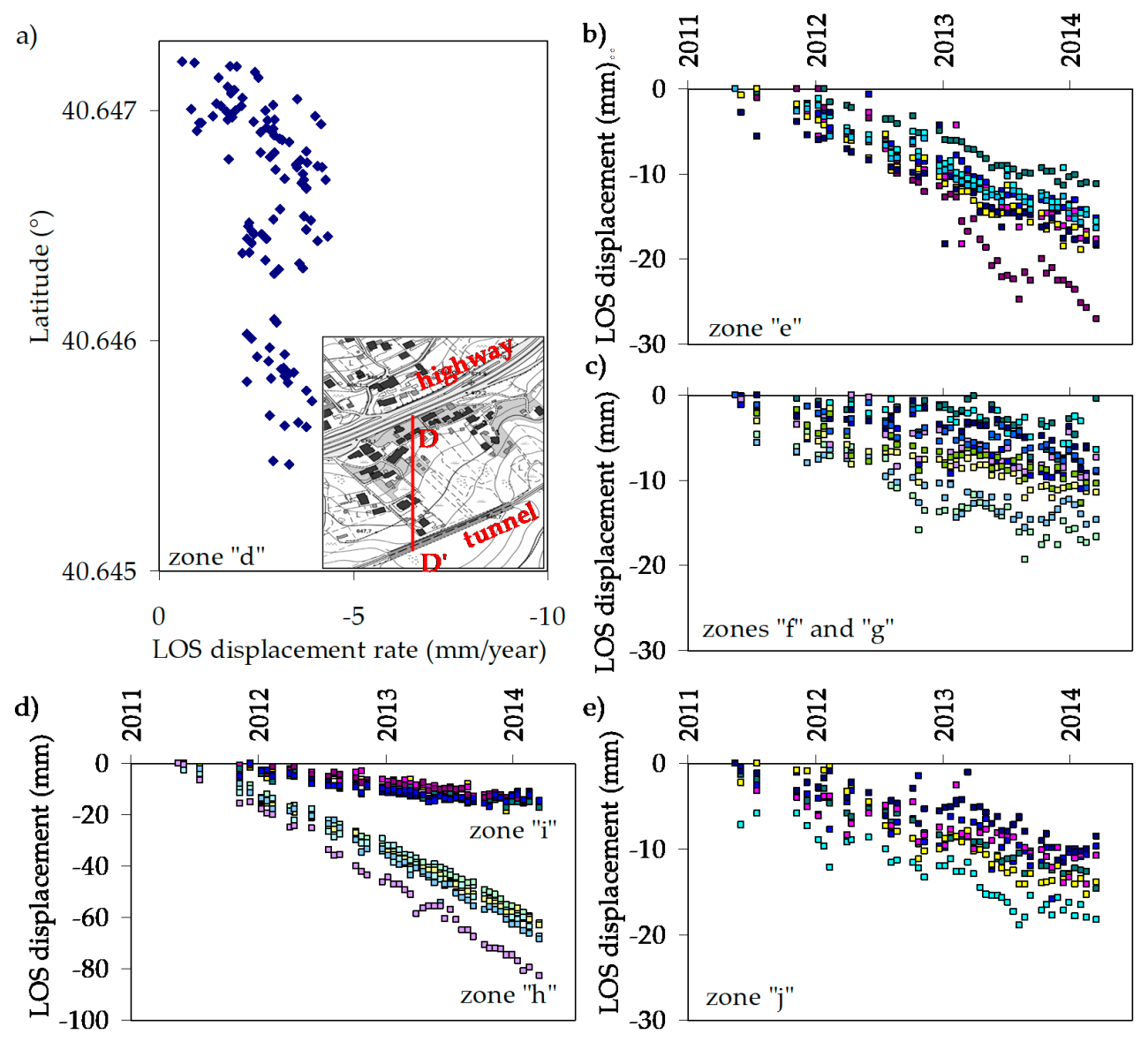

Figure 13. (a) LOS displacement rate against latitude along DD'; (b-e) LOS displacement time series of the groups of scatterers " $\mathrm{e}^{\prime \prime}-\mathrm{j}$ " (location in Figure 11). 


\section{Displacement Field}

The field of the average rates of superficial displacement evaluated in the monitoring period was obtained by using all the available inclinometer, GPS, and PSInSAR data (Figure 14). The results of the topographic measurements are also reported. Figure 14, as a whole, shows the main kinematic features of the two earthflows.

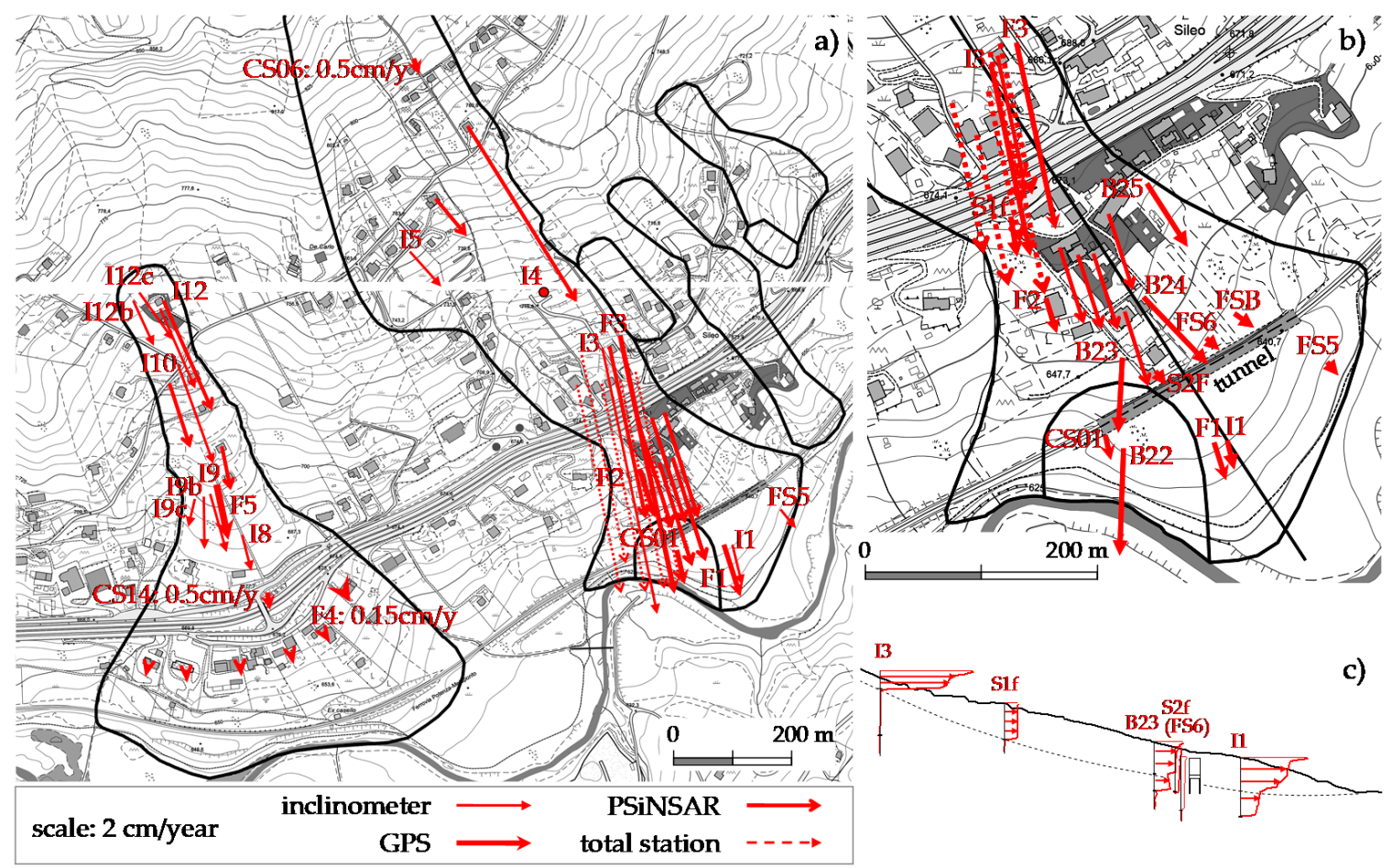

Figure 14. Vectors of average rates of horizontal displacements obtained from inclinometer, GPS, and PSInSAR data in the period May 2011-March 2014 and from topographic measurements carried out in 2010-2011 (a); zoom (b) and longitudinal section (c) of Varco d'Izzo earthflow accumulation.

The yearly average displacement rates in the Costa della Gaveta earthflow determined by inclinometer, GPS, and PSInSAR data are all consistent with each other, both in value and time trend. On the basis of inclinometer profiles (Figure 4), the superficial displacement rates can be also considered representative of the deep displacement. So, the rate field reported in Figure 11 can be considered representative of the movements of the entire landslide body all over the 15-year monitoring period. The displacement rates range from a few $\mathrm{cm} / \mathrm{y}$ to a few $\mathrm{mm} / \mathrm{y}$, decreasing in the downslope direction and becoming negligible in the accumulation. The movement seems continuous along the main axis. The soil discharge crossing the different transversal sections of the landslide can be evaluated from the curves of soil volumes of Figure 15. The volumes were obtained by multiplying the areas of the sections (Figure 4) by the corresponding inclinometer displacements (Figure 5) assumed uniform in each section. The curves relative to the sections through the different inclinometers are very close to each other (Figure 15a). Thus, it seems reasonable to hypothesize a mechanism of movement at constant soil discharge in the landslide channel. The average soil discharge is provided by the slope of the line interpolating the volume series. Figure 15b shows that the Costa della Gaveta earthflow accelerates during rainy periods, with a fast response to rainfall. The way by which this occurs was evaluated experimentally by Di Maio et al. [13]. The correlation between displacement rates and rainfall was quantitatively derived by Vassallo et al. [51]. 
a)
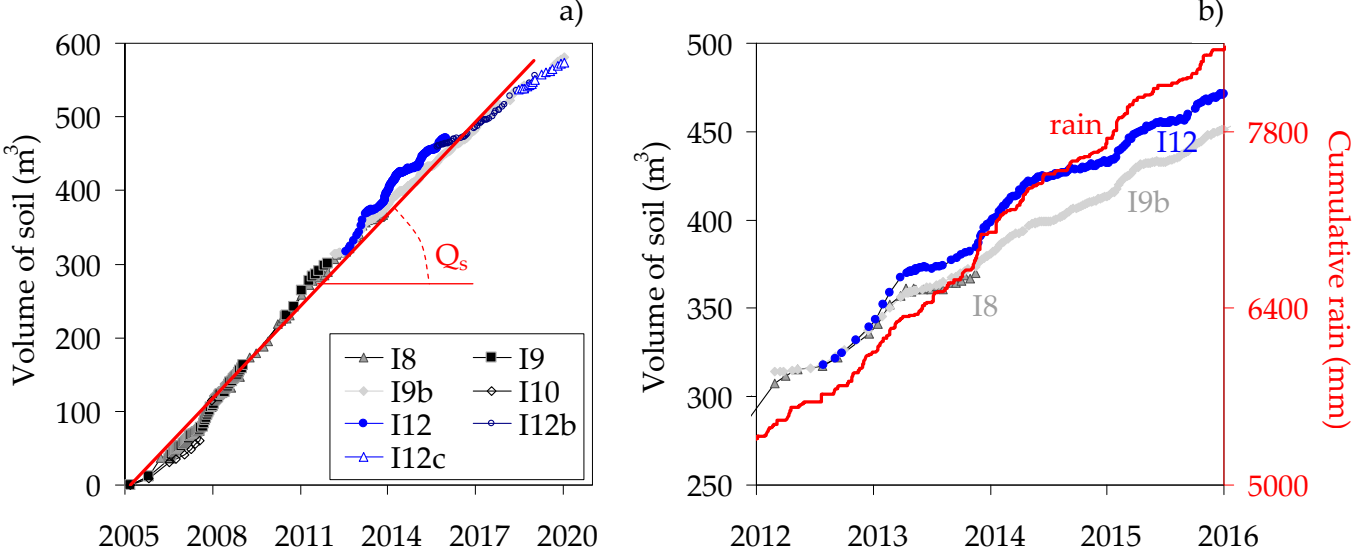

Figure 15. Costa della Gaveta earthflow: volumes of soils, with an indication of the average soil discharge $\mathrm{Q}_{\mathrm{s}}$, crossing the transverse sections through the inclinometers (a), and comparison with cumulative rain (b).

The displacement rates of Varco d'Izzo reported in Figure 14 include the movements along the deepest slip surface; however, these latter are negligible percentages of the total displacements (Figures 6 and 7) and thus the rate field of Figure 14 can be considered representative of the earthflow kinematics. The high levels of anthropogenic modification in this sector do not allow for detailed observation and analysis of the earthflow kinematic zones as in Parise [52] and Guerriero et al. [8]. Nevertheless, the rate field of Figure 14 allows for the identification of three zones which move with different characteristics: (1) the upper zone around I5 and I6 where the displacement rates are in the order of about $1 \mathrm{~cm} / \mathrm{y}$; (2) the zone around I4 that underwent negligible displacements over the monitoring period; (3) the lower zone between $\mathrm{I} 3$ and the river, where the average yearly displacement rates ranged between $7 \mathrm{~cm} / \mathrm{y}$ and $1 \mathrm{~cm} / \mathrm{y}$ along the main longitudinal axis, first decreasing and then increasing in the downslope direction. The overall behavior of the latter zone is probably influenced by the interaction of the landslide with large concrete structures such as retaining walls on deep pile foundations, overpass, tunnel, and buildings. In particular, the zoom from inclinometer I 3 to the Basento river (Figure 14b) shows that the displacement rates decrease approaching the railway tunnel, and then increase downslope from it. This latter, which contrasts the earth movements, is a shallow tunnel re-built in 1992, protected by two sheet pile walls of contiguous piles, $1 \mathrm{~m}$ diameter of and $20 \mathrm{~m}$ length, crossing the upper slip surface. The structure, monitored by distributed fiber-optic sensors, underwent negligible deformations in the observation period [25], consistently with the inclinometer data. The zoom of Figure 14 also shows that the direction and rate of the movements in the landslide foot are influenced by the pronounced bend in the Basento river, where a local slide also occurs.

\section{Conclusions}

The movements of the Costa della Gaveta and Varco d'Izzo earthflows are very slow; however, they cause severe damage to houses and infrastructure. The comprehension of the main features of the landslides' kinematics is vital for the definition of mitigation measures, and is pursued in this work by a composite monitoring system. A long-term displacement monitoring carried out by inclinometers and GPS stations along with PSInSAR and topographic data allowed for reciprocal data validation, spatial and temporal extension of the dataset, and elaboration of a field of displacement rate.

The Costa della Gaveta landslide, an earthflow in a very/extremely slow sliding phase, is characterized by well-defined kinematic features. All over the monitoring period, the soil moved in a well-defined regular track, along a fault line. The displacement rates decrease from a few $\mathrm{cm} / \mathrm{y}$ in the head zone to a few $\mathrm{mm} / \mathrm{y}$ in the accumulation. The variation of the displacement rate along the longitudinal axis can be attributed to the geometry of the landslide channel, characterized by large depth and width variations along its axis. The general mechanism of movement corresponds 
to constant soil discharge along the main track. The average yearly displacement rate was almost constant over the monitoring period, with a slight decrease in the last few years. Seasonal variations overlap the regular general trend. As a remedial measure, a system of deep drains intercepting the slip surface $[13,53]$ is currently under study.

In the case of the Varco d'Izzo landslide system, multiple slip surfaces, internal deformations, and ruptures give the landslide more complex features. The homonymous earthflow occurs along a fault parallel to that of the nearby Costa della Gaveta earthflow. The movement along the longitudinal axis is heterogeneous. The most urbanized zone of the earthflow is also the fastest, with yearly displacement rates ranging between $7 \mathrm{~cm} / \mathrm{y}$ and $1 \mathrm{~cm} / \mathrm{y}$. The variations seem to be influenced by the interaction with the built environment and with the Basento river. Stabilization of the river bank as a remedial measure is currently under study.

Author Contributions: Conceptualization, R.V. and C.D.M.; data curation, R.V., S.C., N.D., J.D.R. and P.G.; funding acquisition, C.D.M.; investigation, R.V., S.C., J.D.R., C.D.M. and P.G., methodology: R.V., S.C., N.D., C.D.M. and P.G.; validation, R.V., S.C., J.D.R., N.D., C.D.M. and P.G.; writing-original draft preparation, R.V., S.C., C.D.M. and P.G.; writing-review \& editing, R.V., J.D.R. and C.D.M. All authors have read and agreed to the published version of the manuscript.

Funding: The geotechnical investigation has been funded by the Basilicata Administrative Region and by the Italian Ministry of Education, University and Research (PRIN 2015: Innovative Monitoring and design strategies for sustainable landslide risk mitigation). The GPS network has been designed by the Geological Survey of Italy ISPRA (Institute for Environmental Protection and Research), in collaboration with the University of Basilicata, with the financial support of the Basilicata Administrative Region - and with the National Civil Protection. Project carried out using $\mathrm{CSK}_{\circledR}$ Products, (C) ASI (Italian Space Agency), delivered under an ASI license to use, provided by the Italian Ministry of Environment.

Acknowledgments: The authors wish to acknowledge M. Belvedere and A. Marotta for carrying out the inclinometer measurements. Particular thanks are given to some members of the ISPRA Institute: G. Buttinelli, G. Carcani, E. Mariani, D. Matarazzo, and B. Porfidia for their technical contribution, and to D. Niceforo for her participation in the GPS campaigns.

Conflicts of Interest: The authors declare no conflict of interest.

\section{References}

1. Esu, F. Behaviour of Slopes in Structurally Complex Formations; AGI, General Report, Int. Symp. on the Geotechnics of Structurally Complex Formations: Capri, Italy, 1977; Volume 2, pp. 292-304.

2. Trigila, A. (Ed.) Report on landslides in Italy. In Italian Landslide Inventory: Methods, Results and Regional Reports; Project IFFI (in Italian). APAT: Roma, Italy, 2007; p. 681.

3. Revellino, P.; Grelle, G.; Donnarumma, A.; Guadagno, F.M. Structurally-controlled earth flows of the Benevento Province (Southern Italy). Bull. Eng. Geol. Environ. 2010, 69, 487-500. [CrossRef]

4. Pellegrino, A.; Ramondini, M.; Urciuoli, G. Interplay between morphology and mechanism of mudslides: Field experiences from Southern Italy. In Landslides: Evaluation and Stvailization, Proceedings of the 9th International Symposium on Landslides, Rio de Janeiro, Brasil, June 28-July 2 2004; Lacerda, W., Ehrlich, M., Fontoura, S.A.B., Sayao, A.S.F., Eds.; Taylor \& Francis Group: London, UK, 2004; Volume 2, pp. 1403-1409.

5. Guida, G.; Iaccarino, G. Fasi evolutive delle frane tipo colata nell'alta valle del F.Basento (Potenza). Proc. Studi Trentini Sci. Nat. Acta Geol. 1991, 68, 127-152.

6. Hungr, O.; Leroueil, S.; Picarelli, L. The Varnes classification of landslide types, an update. Landslides 2014, 11, 67-194. [CrossRef]

7. Urciuoli, G.; Comegna, L.; Di Maio, C.; Picarelli, L. The Basento Valley: A natural laboratory to understand the mechanics of earthflows. Riv. Ital. Geotech. 2016, 50, 71-90.

8. Guerriero, L.; Bertello, L.; Cardozo, N.; Berti, M.; Grelle, G.; Revellino, P. Unsteady sediment discharge in earth flows: Mount Pizzuto earthflow, southern Italy. Geomorphology 2017, 295, 260-284. [CrossRef]

9. Iverson. Regulation of landslide motion by dilatancy and pore pressure feedback. J. Geophys. Res. 2005, 110, F02015.

10. Schulz, W.H.; McKenna, J.P.; Kibler, J.D.; Biavati, G. Relations between hydrology and velocity of a continuously moving landslide—Evidence of pore-pressure feedback regulating landslide motion? Landslides. 2009, 6, 181-190. [CrossRef] 
11. Handwerger, A.L.; Roering, J.J.; Schmidt, D.A. Controls on the seasonal deformation of slow-moving landslides. Earth Planet. Sci. Lett. 2013, 377-378, 239-247. [CrossRef]

12. Guerriero, L.; Diodato, N.; Fiorillo, F.; Revellino, P.; Grelle, G.; Guadagno, F.M. Reconstruction of long-term earth-flow activity using a hydro-climatological model. Nat. Hazards 2015, 77, 1-15. [CrossRef]

13. Di Maio, C.; De Rosa, J.; Vassallo, R.; Coviello, R.; Macchia, G. Hydraulic conductivity and pore water pressures in a clayey earthflow: Experimental data. Geosciences 2020, 10, 102. [CrossRef]

14. Mackey, B.; Roering, J.J. Sediment yield, spatial characteristics, and the long-term evolution of active earthflows determined from airborne LiDAR and historical aerial photographs, Eel River, California. Gsa Bull. 2011, 123, 1560-1576. [CrossRef]

15. Del Soldato, M.; Riquelme, A.; Bianchini, S.; Tomàs, R.; Di Martire, D.; De Vita, P.; Moretti, S.; Calcaterra, D. Multisource data integration to investigate one century of evolution for the Agnone landslide (Molise, southern Italy). Landslides 2018, 15, 2113-2128. [CrossRef]

16. Akbarimehr, M.; Motagh, M.; Haghshenas Haghighi, M. Slope Stability Assessment of the Sarcheshmeh Landslide, Northeast Iran, Investigated Using InSAR and GPS Observations. Remote Sens. 2013, 5, 3681-3700. [CrossRef]

17. Farolfi, G.; Bianchini, S.; Casagli, N. Integration of GNSS and satellite InSAR data: Derivation of fine-scale vertical surface motion maps of Po Plain, Northern Apennines and Southern Alps, Italy. IEEE Trans. Geosc. Rem. Sens. (Tgrs) 2018, 57, 319-328. [CrossRef]

18. Farolfi, G.; Piombino, A.; Catani, F. Fusion of GNSS and satellite radar interferometry: Determination of 3D fine-scale map of present-day surface displacements in Italy as expressions of geodynamics processes. Remote Sens. 2019, 11, 394. [CrossRef]

19. Gullà, G.; Peduto, D.; Borrelli, L.; Antronico, L.; Fornaro, G. Geometric and kinematic characterization of landslides affecting urban areas: The Lungro case study (Calabria, Southern Italy). Landslides 2017, 14, 171-188. [CrossRef]

20. Di Maio, C.; Fornaro, G.; Gioia, D.; Reale, D.; Schiattarella, M.; Vassallo, R. In situ and satellite long-term monitoring of the Latronico landslide, Italy: Displacement evolution, damage to buildings, and effectiveness of remedial works. Eng. Geol. 2018, 245, 218-235. [CrossRef]

21. Calvello, M.; Peduto, D.; Arena, L. Combined use of statistical and DInSAR data analyses to define the state of activity of slow-moving landslides. Landslides 2017, 14, 473-489. [CrossRef]

22. Di Maio, C.; Vassallo, R.; Vallario, M. Plastic and viscous displacements of a deep and very slow landslide in stiff clay formation. Eng. Geol. 2013, 162, 53-66. [CrossRef]

23. Di Maio, C.; Scaringi, G.; Vassallo, R. Residual strength and creep behaviour on the slip surface of specimens of a landslide in marine origin clay shales: Influence of pore fluid composition. Landslides 2015, 12, 657-667. [CrossRef]

24. Di Maio, C.; Vassallo, R.; Scaringi, G.; De Rosa, J.; Pontolillo, D.M.; Grimaldi, G.M. Monitoring and analysis of an earthflow in tectonized clay shales and study of a remedial intervention by $\mathrm{KCl}$ wells. Riv. Ital. Geotech. 2017, 51, 48-63.

25. Minardo, A.; Picarelli, L.; Catalano, E.; Coscetta, A.; Zeni, G.; Zhang, L.; Di Maio, C.; Vassallo, R.; Coviello, R.; Macchia, G.; et al. Distributed Fiber Optic Sensors for the Monitoring of a Tunnel Crossing a Landslide. Remote Sens. 2018, 10, 1291. [CrossRef]

26. Caniani, D.; Pascale, S.; Sdao, F.; Sole, A. Neural networks and landslide susceptibility: A case study of the urban area of Potenza. Nat. Hazards. 2008, 45, 55-72. [CrossRef]

27. Mazzoli, S.; Barkham, S.; Cello, G.; Gambini, R.; Mattioni, L.; Shiner, P.; Tondi, E. Reconstruction of continental margin architecture deformed by the contraction of the Lagonegro Basin, southern Apennines, Italy. J. Geol. Soc. 2001, 158, 309-319. [CrossRef]

28. Cello, G.; Coccia, B.; Mancinelli, A.; Mattioni, L.; Mazzoli, S.; Shiner, P. Architettura pre-orogenica della piatta-forma carbonatica appenninica nell'alta Val d'Agri (Lucania, Italia meridionale). Studi Geol. Camerti 2003, 2, 45-52.

29. Pescatore, T.; Renda, P.; Schiattarella, M.; Tramutoli, M. Stratigraphic and structural relationships between Meso-cenozoic Lagonegro basin and coeval carbonate plat-forms in southern Italy. Tectonophysics 1999, 315, 286-295. [CrossRef]

30. Ogniben, L. Schema introduttivo alla Geologia del confine Calabro-Lucano. Mem. Della Soc. Geol. Ital. 1969, $8,453-763$. 
31. Selli, R. II Paleogene nel quadro della geologia dell'Italia centro meridionale. Mem. Della Soc. Geol. Ital. 1962, 3, 737-789.

32. Vassallo, R.; Grimaldi, G.M.; Di Maio, C.; Di Nocera, S. An earthflow in structurally complex formations of the Italian Southern Apennines: Geological structure and kinematics. In Landslides and Engineered Slopes, Experience, Theory and Practice, Proceedings of the 12th International Symposium on Landslides, Napoli, Italy, 12-19 June 2016; Aversa, S., Cascini, L., Picarelli, L., Scavia, C., Eds.; CRC Press: Boca Raton, FL, USA, 2016; Volume 2, pp. 813-820.

33. Perrone, A.; Iannuzzi, A.; Lapenna, V.; Lorenzo, P.; Piscitelli, S.; Rizzo, E.; Sdao, F. High-resolution electrical imaging of the Varco d'Izzo earthflow (southern Italy). J. Appl. Geophys. 2004, 56, 17-29. [CrossRef]

34. Vassallo, R.; Mishra, M.; Santarsiero, G.; Masi, A. Modeling of Landslide-Tunnel Interaction: The Varco d'Izzo Case Study. Geotech. Geol. Eng. 2019, 37, 5507-5531. [CrossRef]

35. Stark, T.D.; Choi, H. Slope inclinometers for landslides. Landslides 2008, 5, 339-350. [CrossRef]

36. ASTM. Standard Test Method for Monitoring Ground Movement Using Probe-Type Inclinometers. ASTM D6230-98. Annual Book of ASTM Standards; ASTM international: West Conshohocken, PA, USA, 2005.

37. Machan, G.; Bennet, V.G. Use of Inclinometers for Geotechnical Instrumentation on Transportation Projects. State of the Practice. Circular n. E-C129; Transportation Research Board of the National Academies: Washington, DC, USA, 2008.

38. Keefer, D.K.; Johnson, A.M. Earthflows: Morphology, Mobilization and Movement; U.S. Geological Survey Professional Paper 1264; U.S. Geological Survey: Reston, VA, USA, 1983; p. 56.

39. Baum, R.L.; Johnson, A.M. Steady Movement of Landslide Features in Fine-Grained Soils—A Model for Sliding over an Irregular Slip Surface; Chapter D of landslide processes in Utah-Observation and theory; U.S. Geological Survey Bulletin 1842; U.S. Geological Survey: Reston, VA, USA, 1993; pp. D1-D28.

40. Guerriero, L.; Coe, J.A.; Revellino, P.; Grelle, G.; Pinto, F.; Guadagno, F.M. Influence of slip-surface geometry on earth-flow deformation, Montaguto earth flow, southern Italy. Geomorphology 2014, 219, 285-305. [CrossRef]

41. Di Maio, C.; Vassallo, R.; Vallario, M.; Pascale, S.; Sdao, F. Structure and kinematics of a landslide in a complex clayey formation of the Italia Southern Apennines. Eng. Geol. 2010, 116, 311-322. [CrossRef]

42. Di Maio, C.; Vallario, M.; Vassallo, R.; Bianca, M. Displacements of a large landslide in structurally complex clays. In Landslides and Engineered Slopes: Protecting Society through Improved Understanding, Proceedings of the 11th International Symposium on Landslides, Banff, AB, Canada, 3-8 June 2012; Eberhardt, E., Froese, C., Turner, A.K., Leroueil, S., Eds.; CRC Press, Taylor \& Francis Group: London, UK, 2012; Volume 1, pp. 607-613.

43. D'Agostino, N. Complete seismic release of tectonic strain and earthquake recurrence in the Apennines (Italy). Geophys. Res. Lett. 2014, 41, 1155-1162. [CrossRef]

44. Calcaterra, S.; Di Maio, C.; Gambino, P.; Vallario, M.; Vassallo, R. Surface displacements of two landslides evaluated by GPS and inclinometer systems: A case study in Southern Apennines, Italy. Nat. Hazards 2012, 61, 257-266. [CrossRef]

45. Bertiger, W.; Desai, S.; Haines, B.; Harvey, N.; Moore, A.; Owen, S.; Weiss, J. Single receiver phase ambiguity resolution with GPS data. J. Geod. 2010, 84, 327-337. [CrossRef]

46. Scherneck, H.G. A parameterized solid earth tide model and ocean tide loading effects for global geodetic baseline measurements. Geophys. J. Int. 1991, 106, 677-694. [CrossRef]

47. Rebischung, P.; Altamimi, Z.; Ray, J.; Garayt, B. The IGS contribution to ITRF2014. J. Geod. 2016, 90, 611-630. [CrossRef]

48. Dach, R.; Hugentobler, U.; Fridez, P.; Meindl, M. Bernese GPS Software Version 5.0; Astronomical Institute, University of Bern: Bern, Switzerland, 2007.

49. Di Maio, C.; Vassallo, R.; Vallario, M.; Calcaterra, S.; Gambino, P. Surface and deep displacements evaluated by GPS and inclinometers in a clayey slope. In Landslide Science and Practice, Proceedings of the 2nd World Landslide Forum, Rome, Italy, 3-9 October 2011; Margottini, C., Canuti, P., Sassa, K., Eds.; Springer: Berlin/Heidelberg, Germany, 2013; Volume 2, pp. 265-271.

50. Costantini, M.; Ferretti, A.; Minati, F.; Falco, S.; Trillo, F.; Colombo, D.; Novali, F.; Malvarosa, F.; Mammone, C.; Vecchioli, F.; et al. Analysis of surface deformations over the whole Italian territory by interferometric processing of ERS, Envisat and COSMO-SkyMed radar data. Remote Sens. Environ. 2017, 202, 250-275. [CrossRef] 
51. Vassallo, R.; Doglioni, A.; Grimaldi, G.M.; Di Maio, C.; Simeoni, V. Relationships between rain and displacements of an active earth flow: A data driven approach by EPRMOGA. Nat. Hazards 2016, 81, 1467-1482. [CrossRef]

52. Parise, M. Observation of surface features on an active landslide, and implications for understanding its history of movement. Nat. Hazards Earth Syst. Sci. 2003, 3, 569-580. [CrossRef]

53. Baum, R.L.; Reid, M.R. Ground water isolation by low-permeability clays in landslide shear zones. In Landslides in Research, Theory and Practice, Proceedings of the 8th International Symposium on Landslides, Cardiff, UK, 26-30 June 2000; Bromhead, E., Dixon, N., Ibsen, M.-L., Eds.; Thomas Telford: London, UK, 2000; pp. 139-144.

(C) 2020 by the authors. Licensee MDPI, Basel, Switzerland. This article is an open access article distributed under the terms and conditions of the Creative Commons Attribution (CC BY) license (http://creativecommons.org/licenses/by/4.0/). 